\title{
CHRONOLOGY OF CAUVERY DELTA SEDIMENTS FROM SHALLOW SUBSURFACE CORES USING ELEVATED-TEMPERATURE POST-IR IRSL DATING OF FELDSPAR
}

\author{
L. ALAPPAT ${ }^{1}$, S. TSUKAMOTO ${ }^{1}$, P. SINGH ${ }^{2}$, D. SRIKANTH ${ }^{2}$, R. RAMESH ${ }^{3}$ and M. FRECHEN ${ }^{1}$ \\ ${ }^{1}$ Leibniz Institute for Applied Geophysics (LIAG), Section S3: Geochronology and Isotope Hydrology, \\ Stilleweg 2, 30655 Hannover, Germany \\ ${ }^{2}$ Department of Earth Sciences, School of Physical Chemical and Applied Sciences, \\ Pondicherry University, Puducherry - 605 014, India \\ ${ }^{3}$ Institute for Ocean Management, Anna University, Chennai 600 025, India
}

Received 25 February 2010

Accepted 11 June 2010

\begin{abstract}
We present the results of luminescence dating of sediments from two cores from the Cauvery Delta in south-east India. Since all natural quartz OSL signals except one sample were in saturation, the elevated temperature post-IR IRSL protocol for K-feldspar was applied to establish a chronology. Internal dose rates of K-feldspar grains were calculated from the measured internal content of potassium, uranium, thorium and rubidium in the bulk of K-feldspar grains using solution ICP-OES and ICP-MS analysis. A substantial scatter in single-aliquot $D_{e}$ values was observed which is most probably due to the effect of incomplete bleaching of fluvial sediments before burial. A minimum age model was applied to extract possible depositional ages. The study revealed that except an upper layer of Holocene sediments $(<5 \mathrm{~m})$, the majority of the upper $\sim 50 \mathrm{~m}$ of Cauvery delta sediments were deposited between marine isotope stage MIS-5 and MIS-10 or older. The feldspar luminescence ages also indicate the existence of a period of non deposition or erosion in the upper part of the cores.
\end{abstract}

Keywords: Cauvery delta, fluvial sediments, OSL dating, elevated temperature IRSL, K-feldspar.

\section{INTRODUCTION}

Cauvery delta $\left(10^{\circ} 16^{\prime}\right.$ to $11^{\circ} 30^{\prime} \mathrm{N} ; 78^{\circ} 45^{\prime}$ to $79^{\circ} 51^{\prime}$ $\mathrm{E})$ is one of the major sediment repositories in peninsular India and biggest of such in the east coast of Tamil Nadu. The underlying Cauvery Basin is known for its hydrocarbon prospects and the deltaic region has potential aquifer systems particularly along the palaeo- channels and levee deposits (Das, 1991). Majority of the research in Cauvery delta is confined to remote sensing imageries (e.g., Ramasamy, 2006a, b; Ramasamy et al., 2006), geochemical studies on surface sediments (e.g., Ramesh and Subramanian, 1993; Ramanathan et al., 1996; Sharma and Rajamani, 2000, 2001; Singh and Rajamani, 2001a, b), tectonics and geodynamics (e.g., Valdiya, 2001) and sedimentological studies on deeper sediments for hydrocarbon potential (e.g., Kumar, 1983; Chandra et al., 1991). There is little known about the chronology of sediments in this region and the available ages for the upper part of the delta are mainly based on archaeological and radiocarbon dates which have the limitations of dating range. Jaiswal et al. (2009) have studied the slack water deposits in the upper reaches of Cauvery River using optically stimulated luminescence (OSL) dating of quartz. Other major deltaic (e.g. Ganges) and fluvial systems (e.g. Luni River) in India have been studied in the past using luminescence dating method (Kale et al., 2000; Srivastava et al., 2003a, b; Juyal et al., 2000, 2006; Jain et al., 2005; Thomas et al., 2005; 2007; Chandra et al., 2007; Sinha et al., 2007; Gibling et al., 2008).

Little effort has been made so far to reconstruct the comprehensive and sequential history of upper part of the Cauvery Delta based on numerical ages. A systematic application of dating techniques is required, which would provide an insight into the pre-Holocene geomorphologic history of the study area by establishing the chronology of the region. The major aim of the present study is to construct a reliable chronological framework for the upper $(\sim 50 \mathrm{~m})$ sediments of the Cauvery Delta using luminescence dating. 


\section{GEOLOGY AND GEOMORPHOLOGY OF THE AREA}

The region is chiefly underlain by the ArchaeanProterozoic crystalline rocks which constitute gneisses, charnockites and granites and is covered by Quaternary sediments towards the coast. The river basin falls within two major terrains with its head waters flowing through a greenstone- granite terrain (Dharwar Craton) in the north and a granulite terrain in the south. These two terrains are separated by a transition zone of granitic rocks with inclusions of a schist belt towards the north and charnockites and pyroxene granulites and high grade amphibolite assemblages in the south (Sharma and Rajamani, 2001). Towards the east, bound to the Quaternary alluvium in the delta it also features exposures of Cretaceous sediments (Uttatur, Ariyallur and Tiruchirrapalli Formation) and sandstone (Cuddalore Formation) of Mio- Pliocene age. The Quaternary sediments are basically fluvial sediments, middle Holocene beach ridges and late Holocene dune sands (e.g., Kunz et al., 2010). The area is crisscrossed by a number of distributaries of the River Cauvery and few man made channels which bring sediments in to the coastal region.

The Cauvery River originates from the Western Ghats in Karnataka and flows towards east south east over the Mysore plateau to the Bay of Bengal through the state of Tamil Nadu with an approximate aerial coverage of 87,900 km² (Fig. 1; Ramanathan et al.,1996; Singh and Rajamani, 2001b). The upper $\sim 300 \mathrm{~km}$ of the river flows through a low-relief landscape, where as in the down- stream the river flows in a gorge, inset with terraces and cut in to a succession of older erosion surfaces. This transition of geomorphology is attributed to active faulting (Valdiya, 2001), seen together with shift from stable to an uplifting region with the change in crustal rheology from a cold Archaean cratonic region to a hotter crust of Pan-African thermal age (Bridgland and Westaway, 2008). The main tributaries which join Cauvery in the south are Bhavani River from Nilgiri hills and the Amravati River flowing from Annaimalai hills. Though the deltaic region of River Cauvery is mainly under the influence of NE monsoon, the river basin in the upper reaches is controlled mostly by SW monsoon (June to September) which is prominent in the source areas of Western Ghats. The surge of water from the tributaries to the main course of Cauvery during SW monsoon brings a lot of sediment into the deltaic region from the uplands. The tributaries are often dry during the rest of the year. The region experiences a semi-arid tropical climate with mean annual temperature of $25^{\circ} \mathrm{C}$ and the maximum summer (March to May) temperature reaches occasionally up to $43^{\circ} \mathrm{C}$. A number of dams constructed across the river in the recent past have modified the water discharge and sediment accumulation rates in the deltaic region. An average sediment accumulation rate between 0.4 and $4 \mathrm{~mm} / \mathrm{yr}$ for the recent past has been reported in the Cauvery River basin with less sedimentation rate in the tributaries (Ramanathan et al., 1996).

A general geomorphologic map (Fig. 1) was prepared using satellite images (Landsat-ETM, 2000) by visual interpretation based on image characteristics and with the

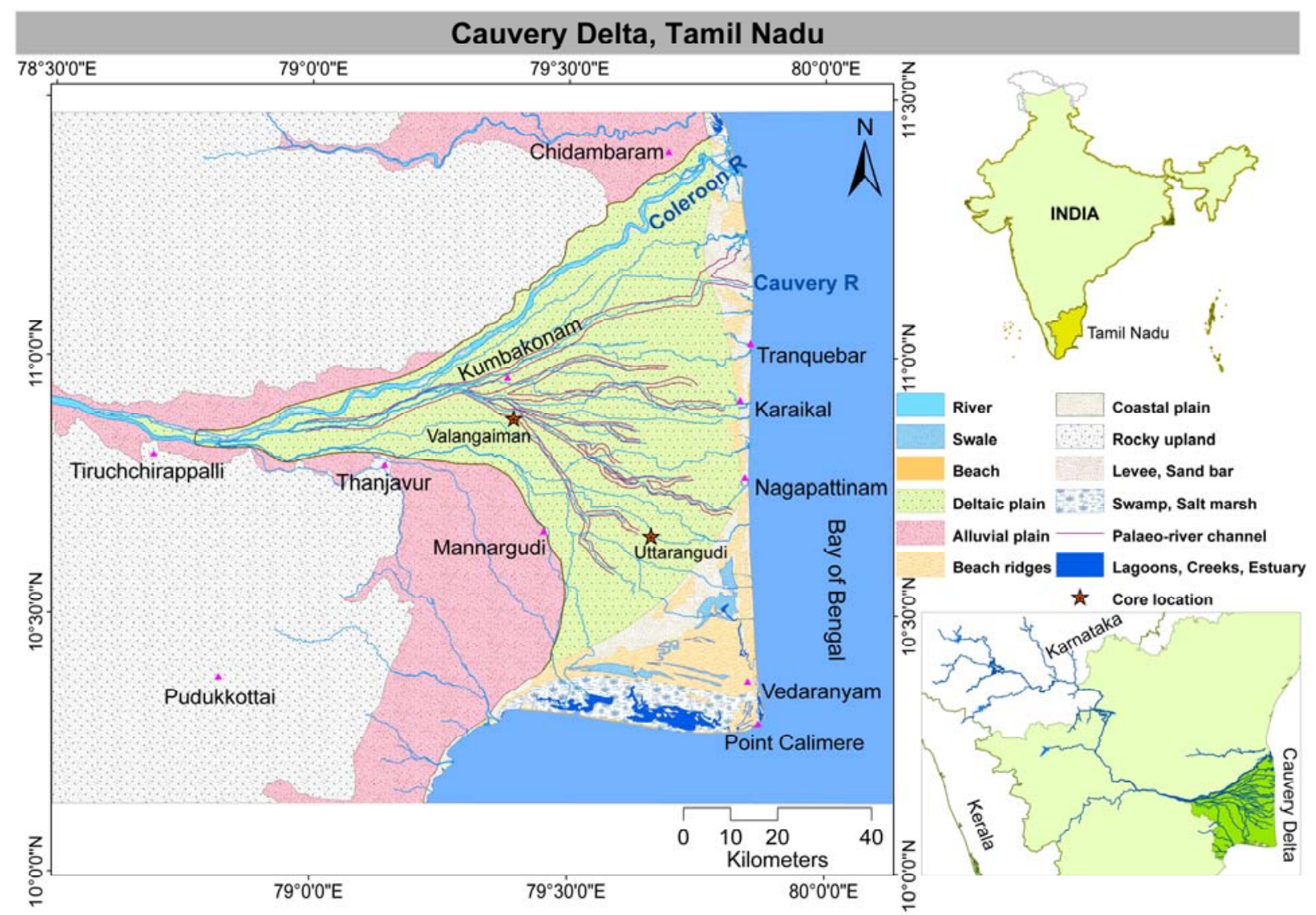

Fig. 1. Map showing the basic geomorphology of the Cauvery Delta region. 
aid of Survey of India Topographic sheets (SOI toposheets, 1970; 1:50,000) as a base map for coastal regions. The map benefitted from various published geomorphologic information of previous studies (Babu, 1991; Ramasamy et al., 2006) combined with field verification at selected areas. The Cauvery Delta is a river dominated delta and is occupied by several of its distributaries. The present delta has developed a triangular pattern with three distinct morphological areas consisting of a marginal denudational unit, a central fluvio- marine depositional unit and a coastal marine depositional unit (Babu, 1991). In this fanning delta with its origin located east of Tiruchirappalli, the present day river flows through the northern channel of the delta as the River Coleroon. From the satellite images one can identify a number of palaeo river channels south of this main channel, which includes the former channel of River Cauvery with its mouth located south of Pumpukar and other tributaries south of this channel. A number of geomorphological features can be identified in the delta region such as palaeo river channels, lagoons, swales, dunes, beach ridges, salt marshes, swamps etc (Fig.1). The Cuddalore Sandstone of Miocene-Pliocene age is seen in the uplands in the western margin of the delta and is outcropped in the north at Jayamkondam region and in the south at the Vallam-Pattukottai-Mannargudi region (Ramasamy et al., 2006). These detached outcrops formerly existed as a continuous unit starting from Pondicherry to Sivaganga in the south west and the present day streams such as Coleroon largely removed this formation (Vaidyanadhan and Ramakrishnan, 2008). The Cuddalore Formation generally comprises of gritty, pebbly to conglomerate, coarse to fine grained argillaceous sandstone, ferruginised and laterised towards the top (Vaidyanadhan and Ramakrishnan, 2008). In the south, MiocenePliocene sandstone of the Vallam area is largely undissected and that of Pattukottai- Mannargudi is highly dissected with gullies and relict butte landforms (Ramasamy et al., 2006).

\section{CORE DESCRIPTION}

Four cores were recovered as a part of a shallow subsurface study programme from the two distinct morphological regions of the delta so as to represent the region. Among these cores two were selected for luminescence dating. The Uttarangudi core (N10 $39^{\prime}$ 17.7'; E79 $39^{\prime}$ 42.2") was recovered from the southern peripheral part of Cauvery Delta located towards north of Thiruthuraipoondi and Valangaiman core (N10 ${ }^{\circ}$ 52' 51.4"; E79 23'38.1") was taken from the central part of the delta south of Kumbakonam (Fig. 1). Eight samples collected from the core "Uttarangudi" (UG-Lum.1715-1722) and three samples from the core "Valangaiman" (VMLum.1723-1725) at varying depths of up to $\sim 55 \mathrm{~m}$ were analysed using luminescence dating.

The Uttarangudi core drilled up to $\sim 55 \mathrm{~m}$ below surface represents various fluvial sedimentary units. A simplified diagrammatic representation of the core lithology is provided in Fig. 2. The uppermost part of the core was chiefly composed of clay, silt and organic matter with intermittent layers of fine to medium sand; whereas the

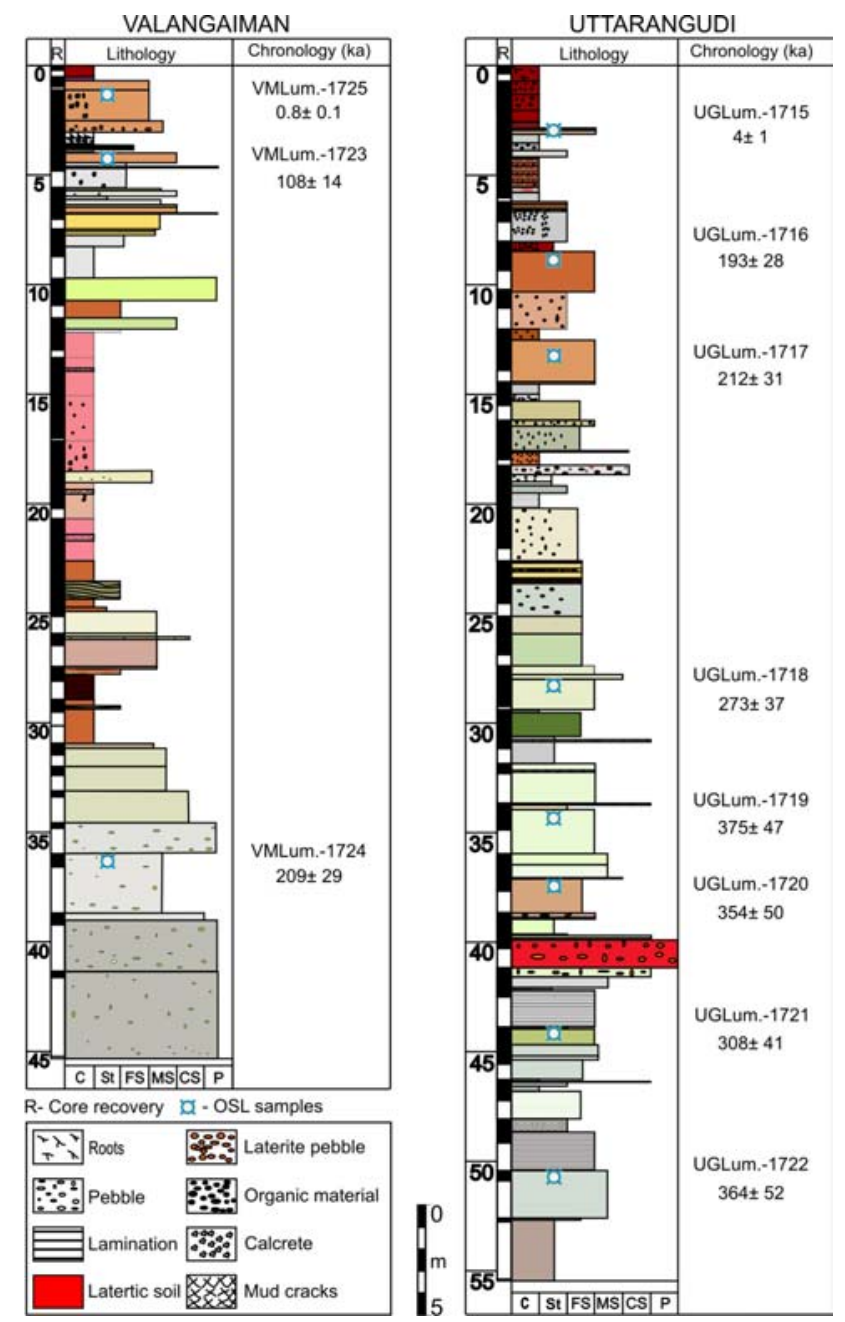

Fig. 2. Diagram showing the lithology and post-IR IRSL feldspar chronology of core Valangaiman and Uttarangudi. The ages presented are 'fading-corrected-MAM' age estimates (Table 2).

remaining part was mostly made up of fine to medium sand with occasional layers of coarse sand and lateritic pebbles. The core represents various stages of fluvial and alluvial activity in the region. The temporal change in the river course is typically represented by the occurrence of alternate organic rich clay layers and re-establishment of active fluvial system is indicated by the presence of thick mainly fine to medium sand units intercalated with pebbles in the core. In the upper part (up to $3 \mathrm{~m}$ ) of the core the clay layers are intercalated with roots, organic materials and calcretes. Fine sand varying from light brown, grey to light green in colour was seen with intercalated mica and alternate layers of pebbles and lenses of clay at varying depths. A distinct bed of $\sim 1 \mathrm{~m}$ thick dark red lateritic soil with pebbles was found in the core at a depth of $40 \mathrm{~m}$ below surface. Eight samples (UGLum.-17151722 ) were collected at depths of 3.05 to $50.6 \mathrm{~m}$ from the Uttarangudi core for luminescence dating.

Valangaiman core shows the sediment units up to a depth of $45 \mathrm{~m}$ below surface (Fig. 2). The upper part of the core contains mainly fine to medium sand with layers of pebbles. The middle part of the core mostly contains red, grey, brownish clay (compacted at places) with dispersed mica. At a depth of $21.5 \mathrm{~m}$ a clay layer was com- 
pacted and it contained mud cracks. A layer of channel sand with pebbles was observed at a depth of $26 \mathrm{~m}$. This layer was underlain by dark brown clay followed by a medium to coarse channel sand with pebbles. Three samples (VMLum.-1723-1725) for luminescence dating were collected from the core, mainly from fine to coarse sand units at depths of $0.91 \mathrm{~m}, 4.7 \mathrm{~m}$ and $36.2 \mathrm{~m}$.

\section{ANALYTICAL PROCEDURES}

The cores were opened under subdued red light conditions to obtain samples for OSL analysis and the outer $1 \mathrm{~cm}$ of the sediments were discarded to avoid possible contamination of bleached and/ or disturbed sediments while recovering the core. Quartz and K-feldspar grain fractions of either $100-150 \mu \mathrm{m}$ and/or $150-250 \mu \mathrm{m}$ were prepared (depending on available quantities) using standard procedures (Aitken, 1998). Quartz grains (2.70$2.62 \mathrm{~g} \mathrm{~cm}^{-3}$ ) were separated from heavy minerals ( $>$ $\left.2.70 \mathrm{~g} \mathrm{~cm}^{-3}\right)$ and K-feldspar $\left(<2.58 \mathrm{~g} \mathrm{~cm}^{-3}\right)$ from the remaining minerals by density separation using aqueous solution of sodium polytungstate $\left(3 \mathrm{Na}_{2} \mathrm{WO}_{4} 9 \mathrm{WO}_{3} \mathrm{H}_{2} \mathrm{O}\right)$. Quartz was etched using 40\% hydrofluoric acid (HF) for 60 minutes to remove feldspar contamination and the outer layer of quartz grains to avoid the influence of alpha particles in the dose rate calculation. The samples were then washed with distilled water and re-sieved to remove grains that had become smaller during this process. The K-feldspar extracts were not treated with HF.

An automated Risø TL/OSL DA-20 reader equipped with a ${ }^{90} \mathrm{Sr} /{ }^{90} \mathrm{Y}$ beta source delivering a dose rate of $0.118 \mathrm{~Gy} \mathrm{~s}^{-1}$ was used for the measurements. Blue-LED arrays of $470 \pm 20 \mathrm{~nm}$ and IR-diodes of $870 \pm 40 \mathrm{~nm}$ were used for the optical stimulation of quartz and K-feldspar respectively. The filter packs of Hoya U-340 (7.5 mm) for quartz and Corning 7-59 (4 mm) in combination with Schott BG-39 (2 mm) for K-feldspar measurements were employed. This was to exclude unwanted signals during the emission and to prevent stimulating light from entering the photomultiplier tube (PMT).

External dose rates were calculated from the concentrations of radioactive isotopes of $\mathrm{K}, \mathrm{Th}$, and $\mathrm{U}$ in the surrounding sediments measured using a high resolution gamma spectrometer (High Purity Germanium - HPGe n-type detector). The remaining sediments left after luminescence sampling from each core were utilized for dose rate determination. The bulk of the collected sample was dried at $50^{\circ} \mathrm{C}$ and crushed to achieve a homogeneous grain size. The samples were then filled into $50 \mathrm{~g}$ plastic containers for gamma measurements. The prepared samples were sealed air tight and stored for one month to attain ${ }^{222} \mathrm{Rn}-{ }^{226} \mathrm{Ra}$ equilibrium and then used for measurements. Each sample was measured for 36 hrs.

The K-feldspar grains separated using heavy liquid from the same fraction that was used for the OSL measurements were digested using $\mathrm{HNO}_{3}$ and $\mathrm{HF}$ acid. The prepared samples were analysed using ICP-OES (Inductively Coupled Plasma Optical Emission Spectroscopy) for K-content. Internal concentrations of uranium, thorium and rubidium in the $\mathrm{K}$-feldspar grains of the sample were determined using solution ICP-MS (Inductively Coupled Plasma Mass Spectrometry) analysis. The meas- ured concentrations of K (\%), U (ppm), Th (ppm) and Rb $(\mathrm{ppm})$ are given in the Table $\mathbf{1}$.

The dose rate conversion factors of Adamiec and Aitken (1998) and beta attenuation factors of Mejdahl (1979) were applied for calculation of dose rate. Absorbed beta dose fractions for $\mathrm{K}$ and rubidium for the selected grain diameter were taken from Mejdahl (1979) and Readhead (2002). The samples were analysed for in situ water content yieldeding values between $8 \%$ up to a maximum of $20 \%$ of its dry weight. We applied an average moisture content of $15 \%$ with a relative uncertainty of $5 \%$ in the dose rate calculation. An a-value of $0.08 \pm 0.02$ (ReesJones, 1995; Wallinga et al., 2001) was applied in the calculation of dose rate for feldspar. The internal alpha dose rate for quartz grains are reported in previous studies for similar grain size (e.g., Vandenberghe et al., 2008: $\sim 0.010 \pm 0.002 \mathrm{mGy} \mathrm{a}^{-1}$; Berger et al., 2009: $\sim 0.06 \pm 0.03 \mathrm{mGy} \mathrm{a}^{-1}$ ) and were considered as negligible given the relatively high external dose rate $(1.02 \pm 0.12$ to $1.55 \pm 0.16 \mathrm{mGy} \mathrm{a}^{-1}$ ) (Table 2) for the quartz samples.

\section{OSL of Quartz}

The coarse grain quartz samples were mounted on stainless steel discs using small size mask ( $\sim 2 \mathrm{~mm}$ diameter) to be able to make aliquots with a few tens to about a hundred grains on each disc and 40 such aliquots were used for each measurement. The $D_{e}$ values were calculated using a standard SAR protocol (Murray and Wintle, 2000; Wintle and Murray, 2006) including the test of OSL IR depletion ratio (Duller, 2003) to check IR sensitive minerals in the sample. The measured $D_{e}$ values of quartz were rejected for poor recycling ratio $(>1.0 \pm 0.1)$, high recuperation ( $>5 \%$ of natural) and for poor IR depletion ratio $(>1.00 \pm 0.15)$. For most of the samples even after $1 \mathrm{hr}$ of $\mathrm{HF}$ etching prior to measurement there was a substantial amount of IR associated signal and these samples were re-etched to remove remaining contaminants. Measurement uncertainty of $1.5 \%$ was incorporated in the $D_{e}$ calculation. The OSL signals of first $0.6 \mathrm{~s}$ were integrated and used for the calculation of $D_{e}$ after subtracting the last $4 \mathrm{~s}$ of background.

Dose recovery tests at varying preheat conditions were carried out to find the appropriate preheat-cut heat combination prior to $D_{e}$ measurements. It was observed that at lower temperatures of up to $160-260^{\circ} \mathrm{C}$ the dose recovery ratio was at an average of $\sim 30 \%$ lower to that of the given dose. A pulse annealing experiment was then carried out to determine the thermal stability of different components in the sample. This was done to check if there was a thermally unstable medium component which may lead to significant underestimation of $D_{e}$ values (Li and Li, 2006; Pawley et al., 2009). The pulse annealing test involves the sensitisation of sample by subjecting it to repeated cycles of heating to $450^{\circ} \mathrm{C}$ at $5^{\circ} \mathrm{C} \mathrm{s}^{-1}$ and beta irradiation of $60 \mathrm{~Gy}$. The samples were then given a beta dose of 120 Gy and OSL signal was measured after preheating at different temperature between 160 and $360^{\circ} \mathrm{C}$. The intensity of the fast component increases up to 280$300^{\circ} \mathrm{C}$ and then it declines rapidly above $320^{\circ} \mathrm{C}$. The medium component appeared to be thermally unstable as signal intensity declines gradually with increasing temperatures above $220^{\circ} \mathrm{C}$ (Fig. 3a). The dose recovery tests 
were repeated with new set of preheat-cut heat temperature combination of $280^{\circ} \mathrm{C} / 260^{\circ} \mathrm{C}$ (the condition which gives the highest fast component dominated OSL signal) which recovered the given dose within the ratio of 1.03 .

The maximum age limit that one sample can reach for luminescence dating is controlled by its dose saturation levels, $D_{0}$ (Singarayer and Bailey, 2003). It is evident from the dose response curve that the sample is in saturation. An exponential plus linear fit was used for the samples and the resultant $D_{e}$ in most of the samples was much higher than the characteristic $D_{0}$ value (for e.g. UGLum.-1719) (Fig. 3b). It is considered that the samples are saturated when $D_{e}$ exceeds $2 \mathrm{D}_{0}$ (Wintle and Murray, 2006), and the apparent $D_{e}$ would be underestimating the real burial dose of the sample. Except for the uppermost sample of Uttarangudi core (UGLum.-1715) all the quartz samples analysed were in saturation with $D_{e}$ being greater than or very close to $2 \mathrm{D}_{0}$ (Table 2) and hence cannot be used to calculate the true depositional age for the given sample.

\section{IRSL of K-feldspar}

Feldspar generally gives brighter luminescence signal than quartz and as its level of saturation dose is much higher it can provide a better estimate of burial age even for old sediments (e.g., Wallinga et al., 2007). The beta dose from internal radioactive elements $(\mathrm{K}, \mathrm{U}, \mathrm{Th}$ and $\mathrm{Rb})$ contributes significantly $(\sim 30 \%)$ to the total dose rate of K-feldspar (Table 1) and is less dependent on external nuclear radiation compared to quartz (e.g., Wintle, 2008; Li et al., 2008).

It has been demonstrated that the use of an elevated temperature for IRSL measurements reduces laboratory fading rates considerably compared to the IRSL signal measured at $50^{\circ} \mathrm{C}$ (Thomsen et al., 2008; Buylaert et al., 2009). The elevated temperature post-IR IRSL SAR protocol of Buylaert et al. (2009) was employed therefore in this study. We used $225^{\circ} \mathrm{C}$ IR stimulation after stimulating the sample at $50^{\circ} \mathrm{C}$ and confirmed that the signals were less affected by anomalous fading when high temperature $\left(225^{\circ} \mathrm{C}\right)$ stimulation was used. The suitability of the protocol to the samples in this study was verified using a dose recovery test. The protocol recovered the given dose with the ratio of $0.97(n=66)$. Small sized aliquots, each having $\sim 25$ grains, were used for Kfeldspar measurements.

The protocol uses an identical heat treatment of $250^{\circ} \mathrm{C}$ for $60 \mathrm{~s}$ prior to the regenerated and test dose IRSL measurements and a $40 \mathrm{~s}$ high temperature $\left(290^{\circ} \mathrm{C}\right)$ hot bleach at the end of each cycle. The IRSL signal was first measured at $50^{\circ} \mathrm{C}$ and then at $225^{\circ} \mathrm{C}$ for $100 \mathrm{~s}$. The $D_{e}$ values were calculated for both stimulation temperatures by integrating the initial $2 \mathrm{~s}$ of IRSL signal with the last 10 s of signal subtracted as background.

Because feldspars typically have unstable signals due to anomalous fading (e.g., Aitken, 1985) laboratory fading rates were calculated using the formula of Huntley and Lamothe (2001) to permit age corrections. Further

Table 1. Details of feldspar dose rate measurements. Internal potassium content (\%) was measured in the bulk of K-feldspar grain using ICP-OES and concentrations of $U$, Th and Rb in the K-feldspar grains were measured using ICP-MS. An average water content of $15 \pm 5 \%$ was applied in the calculation. The $\mathrm{K}, \mathrm{U}$ and Th concentrations in the sediment was measured using high-resolution gamma spectrometer. An average water content of $15 \pm 5 \%$ was applied in the calculation.

\begin{tabular}{|c|c|c|c|c|c|c|c|c|c|c|c|}
\hline \multirow{2}{*}{ Sample } & \multicolumn{4}{|c|}{ Data for internal dose rate calculation } & \multirow{2}{*}{$\begin{array}{l}\text { Internal } \\
\text { dose rate } \\
\text { (mGy/a) }\end{array}$} & \multicolumn{3}{|c|}{ Data for external dose rate calculation } & \multirow{2}{*}{$\begin{array}{c}\text { External } \\
\text { dose rate } \\
\text { (mGy/a) }\end{array}$} & \multirow{2}{*}{$\begin{array}{c}\text { Cosmic } \\
\text { radiation } \\
\text { dose } \\
\text { (mGy/a) }\end{array}$} & \multirow{2}{*}{$\begin{array}{c}\text { Total dose } \\
\text { rate (D) } \\
\text { (mGy/a) }\end{array}$} \\
\hline & $\begin{array}{c}\mathrm{K} \\
(\%)\end{array}$ & $\begin{array}{l}\text { Thorium } \\
\text { (ppm) }\end{array}$ & $\begin{array}{l}\text { Uranium } \\
\text { (ppm) }\end{array}$ & $\begin{array}{l}\text { Rubidium } \\
\text { (ppm) }\end{array}$ & & $\begin{array}{c}\mathrm{K} \\
(\%)\end{array}$ & $\begin{array}{l}\text { Thorium } \\
\text { (ppm) }\end{array}$ & $\begin{array}{l}\text { Uranium } \\
\text { (ppm) }\end{array}$ & & & \\
\hline UG Lum.-1715* & $11.47 \pm 0.57$ & $0.121 \pm 0.006$ & $0.029 \pm 0.001$ & $0.107 \pm 0.005$ & $0.65 \pm 0.03$ & $0.42 \pm 0.01$ & $7.00 \pm 0.06$ & $0.89 \pm 0.02$ & $0.90 \pm 0.09$ & & \\
\hline UG Lum.-1716* & $11.44 \pm 0.57$ & $0.136 \pm 0.007$ & $0.039 \pm 0.002$ & $0.036 \pm 0.002$ & $0.65 \pm 0.03$ & $1.09 \pm 0.01$ & $5.44 \pm 0.05$ & $0.45 \pm 0.02$ & $1.28 \pm 0.09$ & $0.050 \pm 0.004$ & $1.98 \pm 0.26$ \\
\hline UG Lum.-1717* & $12.25 \pm 0.61$ & $0.225 \pm 0.011$ & $0.054 \pm 0.003$ & $0.236 \pm 0.012$ & $0.70 \pm 0.03$ & $1.02 \pm 0.02$ & $3.76 \pm 0.06$ & $0.37 \pm 0.02$ & $1.12 \pm 0.09$ & $0.031 \pm 0.003$ & $1.85 \pm 0.25$ \\
\hline UG Lum.-1718† & $12.42 \pm 0.62$ & $1.214 \pm 0.061$ & $0.032 \pm 0.002$ & $0.041 \pm 0.002$ & $0.55 \pm 0.03$ & $0.73 \pm 0.01$ & $8.98 \pm 0.08$ & $0.90 \pm 0.02$ & $1.29 \pm 0.09$ & $0.017 \pm 0.009$ & $1.85 \pm 0.24$ \\
\hline UG Lum.-1719† & $12.01 \pm 0.60$ & $0.217 \pm 0.011$ & $0.067 \pm 0.003$ & $0.058 \pm 0.003$ & $0.51 \pm 0.02$ & $1.15 \pm 0.02$ & $8.85 \pm 0.07$ & $0.95 \pm 0.02$ & $1.64 \pm 0.09$ & $0.020 \pm 0.009$ & $2.17 \pm 0.27$ \\
\hline UG Lum.-1720* & $12.43 \pm 0.62$ & $0.092 \pm 0.005$ & $0.026 \pm 0.001$ & $0.037 \pm 0.002$ & $0.71 \pm 0.03$ & $0.42 \pm 0.01$ & $8.87 \pm 0.08$ & $1.36 \pm 0.03$ & $1.09 \pm 0.09$ & $0.023 \pm 0.008$ & $1.82 \pm 0.25$ \\
\hline UG Lum.-1721† & $12.57 \pm 0.63$ & $0.062 \pm 0.003$ & $0.012 \pm 0.001$ & $2.662 \pm 0.133$ & $0.52 \pm 0.03$ & $0.82 \pm 0.02$ & $11.32 \pm 0.11$ & $1.10 \pm 0.04$ & $1.53 \pm 0.09$ & $0.042 \pm 0.012$ & $2.09 \pm 0.26$ \\
\hline UG Lum.-1722† & $12.06 \pm 0.60$ & $0.117 \pm 0.006$ & $0.021 \pm 0.001$ & $0.094 \pm 0.005$ & $0.50 \pm 0.02$ & $1.14 \pm 0.02$ & $6.05 \pm 0.08$ & $0.69 \pm 0.03$ & $1.42 \pm 0.09$ & $0.095 \pm 0.006$ & $2.02 \pm 0.26$ \\
\hline VM Lum.-1725 & $12.20 \pm 0.61$ & $0.245 \pm 0.012$ & $0.103 \pm 0.005$ & $0.121 \pm 0.006$ & $0.42 \pm 0.02$ & $1.51 \pm 0.02$ & $14.86 \pm 0.10$ & $1.16 \pm 0.03$ & $2.33 \pm 0.09$ & $0.184 \pm 0.005$ & $2.94 \pm 0.35$ \\
\hline VM Lum.-1723* & $12.09 \pm 0.61$ & $0.172 \pm 0.009$ & $0.049 \pm 0.002$ & $0.122 \pm 0.008$ & $0.69 \pm 0.03$ & $1.32 \pm 0.02$ & $10.69 \pm 0.08$ & $0.69 \pm 0.03$ & $1.81 \pm 0.09$ & $0.100 \pm 0.017$ & $2.60 \pm 0.32$ \\
\hline VM Lum.-1724* & $11.71 \pm 0.59$ & $0.172 \pm 0.009$ & $0.062 \pm 0.003$ & $0.168 \pm 0.006$ & $0.67 \pm 0.03$ & $1.28 \pm 0.02$ & $6.53 \pm 0.06$ & $0.47 \pm 0.02$ & $1.50 \pm 0.09$ & $0.024 \pm 0.007$ & $2.20 \pm 0.28$ \\
\hline
\end{tabular}


Table 2. Summary of quartz measurement details (number of aliquots accepted/measured (n), $D_{e}$, and OSL age). Errors here and in Table 3 are $1 \sigma$.

\begin{tabular}{|c|c|c|c|c|c|c|c|c|}
\hline Lum. No. & $\mathrm{n}$ & $\begin{array}{c}\text { Over- } \\
\text { dispersion, } \\
\sigma_{\mathrm{d}}(\%)\end{array}$ & $\begin{array}{l}\text { Grain size } \\
(\mathrm{m})\end{array}$ & $\begin{array}{l}D_{e} \\
\text { (Gy) }\end{array}$ & $\begin{array}{l}2 D_{0} \\
\text { (Gy) }\end{array}$ & $\begin{array}{c}\text { Dose rate D } \\
\text { (mGy/a) }\end{array}$ & $\begin{array}{l}\text { Age } \\
\text { (ka) }\end{array}$ & MAM- age \\
\hline UG Lum.-1715 & $43(44)$ & 31 & $150-250$ & $6.1 \pm 2.8$ & 40 & $1.02 \pm 0.12$ & $6 \pm 1$ & $4 \pm 1$ \\
\hline UG Lum.-1716 & $36(40)$ & 27 & $150-250$ & $153 \pm 48$ & 120 & $1.29 \pm 0.14$ & $>118^{\S}$ & - \\
\hline UG Lum.-1717 & $32(40)$ & 34 & $150-200$ & $155 \pm 55$ & 90 & $1.16 \pm 0.13$ & $>134 \S$ & - \\
\hline UG Lum.-1718 & $32(40)$ & 23 & $100-150$ & $221 \pm 56$ & 110 & $1.17 \pm 0.13$ & $>189 \S$ & - \\
\hline UG Lum.-1719 & $29(42)$ & 28 & $100-150$ & $127 \pm 51$ & 103 & $1.55 \pm 0.16$ & $>82^{\S}$ & - \\
\hline UG Lum.-1720 & $28(40)$ & 32 & $150-200$ & $206 \pm 68$ & 111 & $1.05 \pm 0.12$ & $>197 \S$ & - \\
\hline UG Lum.-1721 & $28(40)$ & 32 & $100-150$ & $226 \pm 82$ & 123 & $1.51 \pm 0.16$ & $>150 \S$ & - \\
\hline UG Lum.-1722 & $31(38)$ & 42 & $100-150$ & $140 \pm 73$ & 137 & $1.46 \pm 0.16$ & $>96 \S$ & - \\
\hline
\end{tabular}

\$- minimum depositional age due to saturation of quartz OSL signal.

Table 3. Summary of data showing the sample details, $D_{e}$ distribution characteristics and statistics of the measured IRSL and post-IR IRSL. The over dispersion, $\sigma_{d}$ represents the relative standard deviation of the measured single aliquot $D_{e}$ distribution obtained using the 'central age model'. The number of accepted aliquots ' $n$ ' using the acceptance criteria are given with the total measured aliquots in the brackets. Sample ages for IRSL and post-IR IRSL signals obtained using weighted mean $D_{e}$ and minimum age model, fading rate (' $\mathrm{g}$ ') and fading corrected ages are shown. Inferred final ages are highlighted in bold.

\begin{tabular}{|c|c|c|c|c|c|c|c|c|c|c|c|c|c|}
\hline \multirow[b]{2}{*}{ Sample } & \multirow[b]{2}{*}{$\begin{array}{l}\text { Depth } \\
\text { (m) }\end{array}$} & \multirow[b]{2}{*}{$\mathrm{n}$} & \multicolumn{3}{|c|}{ Descriptive statistics } & \multicolumn{4}{|c|}{ Age IRSL $50^{\circ} \mathrm{C}$} & \multicolumn{4}{|c|}{ Age post IR IR $225^{\circ} \mathrm{C}$} \\
\hline & & & $\begin{array}{c}\text { Over- } \\
\text { dispersion, } \\
\sigma_{d}(\%)\end{array}$ & Skew & Kurtosis & $\begin{array}{l}D_{e} \\
\text { (Gy) }\end{array}$ & $\begin{array}{l}\text { Age } \\
\text { (ka) }\end{array}$ & $\begin{array}{c}\text { 'g' value } \\
\text { (\%/decade) }\end{array}$ & $\begin{array}{l}\text { Fading } \\
\text { corrected } \\
\text { age (ka) }\end{array}$ & $\begin{array}{l}D_{e} \\
\text { (Gy) }\end{array}$ & $\begin{array}{c}\text { 'g' value } \\
\text { (\%/decade) }\end{array}$ & $\begin{array}{l}\text { Fading } \\
\text { corrected } \\
\text { age (ka) }\end{array}$ & $\begin{array}{l}\text { Fading } \\
\text { corrected } \\
\text { MAM- age } \\
\text { (ka) } \\
\end{array}$ \\
\hline UG Lum.-1715* & 3.05 & $23(24)$ & 47 & 2.6 & 6.6 & $6.5 \pm 1.9$ & $4 \pm 1$ & $14.7 \pm 0.6$ & - & $8.2 \pm 2.7$ & $2.9 \pm 0.5$ & $6 \pm 1$ & $4 \pm 1$ \\
\hline UG Lum. $-1716^{*}$ & 9.13 & $24(24)$ & 15 & -0.1 & -0.5 & $288 \pm 37$ & $145 \pm 19$ & $4.2 \pm 0.4$ & $211 \pm 33$ & $407 \pm 59$ & $0.9 \pm 0.3$ & $220 \pm 29$ & $193 \pm 28$ \\
\hline UG Lum.-1717* & 13.58 & $22(24)$ & 16 & 0.7 & 0.7 & $316 \pm 56$ & $170 \pm 24$ & $4.3 \pm 0.4$ & $252 \pm 43$ & $407 \pm 59$ & $1.0 \pm 0.2$ & $238 \pm 33$ & $212 \pm 31$ \\
\hline UG Lum.-1718† & 28.50 & $19(24)$ & 15 & -0.4 & 0 & $392 \pm 58$ & $211 \pm 28$ & $6.5 \pm 0.3$ & $422 \pm 59$ & $523 \pm 71$ & $0.5 \pm 0.2$ & $293 \pm 39$ & $273 \pm 37$ \\
\hline UG Lum.-1719† & 34.47 & $16(24)$ & 3 & -1.4 & 1.2 & $480 \pm 48$ & $221 \pm 28$ & $5.8 \pm 0.7$ & $397 \pm 71$ & $769 \pm 49$ & $1.0 \pm 0.2$ & $382 \pm 48$ & $375 \pm 47$ \\
\hline UG Lum. $-1720^{*}$ & 37.25 & $15(24)$ & 12 & 0.2 & -0.7 & $442 \pm 81$ & $241 \pm 35$ & $4.3 \pm 0.7$ & $360 \pm 85$ & $666 \pm 87$ & $1.2 \pm 0.4$ & $400 \pm 57$ & $354 \pm 50$ \\
\hline UG Lum.-1721† & 44.35 & $20(24)$ & 7 & 0.4 & 0.4 & $470 \pm 50$ & $223 \pm 29$ & $4.6 \pm 0.3$ & $344 \pm 50$ & $598 \pm 50$ & $1.6 \pm 0.3$ & $323 \pm 41$ & $308 \pm 41$ \\
\hline UG Lum.-1722† & 50.60 & $20(24)$ & 15 & 0.5 & -0.6 & $234 \pm 42$ & $116 \pm 15$ & $12.8 \pm 0.8$ & - & $484 \pm 71$ & $1.0 \pm 0.2$ & $408 \pm 54$ & $364 \pm 52$ \\
\hline VM Lum.-1725‡ & 0.91 & $9(24)$ & 3 & 2.7 & 7.7 & $0.6 \pm 0.4$ & $0.2 \pm 0.1$ & $12.5 \pm 0.7$ & $0.6 \pm 0.2$ & $2.1 \pm 0.8$ & $2.8 \pm 0.4$ & $0.7 \pm 0.1$ & $0.8 \pm 0.1$ \\
\hline VM Lum.-1723* & 4.70 & $21(24)$ & 9 & 0.6 & 0.2 & $213 \pm 21$ & $82 \pm 10$ & $3.4 \pm 0.2$ & $109 \pm 15$ & $286 \pm 26$ & $5.4 \pm 0.1$ & $116 \pm 14$ & $108 \pm 14$ \\
\hline VM Lum.-1724* & 36.20 & $23(24)$ & 17 & -0.1 & 0.1 & $344 \pm 60$ & $156 \pm 20$ & $3.9 \pm 0.4$ & $222 \pm 36$ & $461 \pm 62$ & $1.5 \pm 0.1$ & $236 \pm 30$ & $209 \pm 29$ \\
\hline
\end{tabular}

detailed description and physical mechanism behind anomalous fading can be found in Aitken (1998 - Appendix D). The ' $g$ ' value (Aitken, 1985) was calculated as a measure of fading rate corresponding to the unit of percentage per decade of time, which was then used to correct the IRSL ages when the $D_{e}$ values of respective samples were within the linear part of the dose response curve (Huntley and Lamothe, 2001). All samples were tested for anomalous fading using six aliquots each.

\section{Differential bleaching}

It has been reported that signal resetting in feldspar grains is slower than that of quartz (e.g. Godfrey-Smith et al., 1988; Klasen et al., 2006) which may contribute to the retention of some residual signal in feldspar measurements. In the current study, we selected a few random samples and bleached the aliquots for $4 \mathrm{hrs}$ in a solar stimulator and measured it using the same measurement protocol. After bleaching, the older samples (UG Lum.$1721,-1722,-1723,-1724$ ) retained only $\sim 3$ Gy as residual for post-IR IRSL and $\sim 1.5$ Gy for IRSL signal which is in general $<1 \%$ of the $D_{e}$ value of the sample. This suggests the ability of the samples to be bleached almost completely upon exposure to sunlight.

The shape of the measured dose distribution can be used to infer the degree of bleaching at the time of depo- 

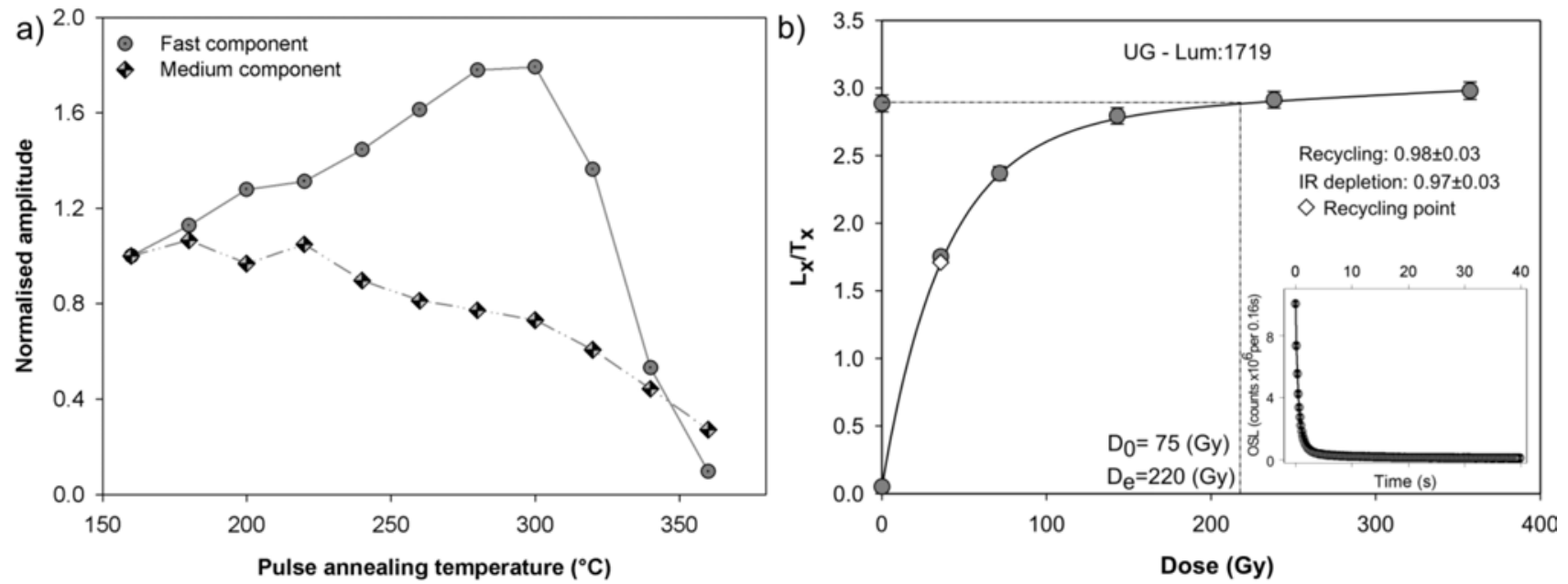

Fig. 3. (a) Normalised OSL components observed during pulse annealing with medium and slow components showing thermal instability at increasing temperature. (b) SAR growth curve showing saturation for a selected quartz sample (UG Lum: 1719) with inset shows the natural decay curve. A preheat of $280^{\circ} \mathrm{C}$ and a cut heat of $260^{\circ} \mathrm{C}$ was used for all measurements.

sition (e.g., Olley et al., 1999; Rodnight et al., 2006). The skewed $D_{e}$ distribution indicates that the grains were differentially bleached prior to deposition, with a few grains being well bleached and few being exposed for a brief period and some that were not at all exposed to daylight. An increasing asymmetry in the distributions may suggest a greater likelihood that the aliquots with lower $D_{e}$ are close to the true burial dose (Olley et al., 1999). The $D_{e}$ distributions of measured K-feldspar aliquots for most of the samples were highly scattered with significant values of skewness (-1.4 to 2.7$)$ and kurtosis $(-0.6$ to 7.7$)$. The over dispersion values ranged between 3 to $47 \%$ for feldspar measurements (Table 3 ) and between 28 to $43 \%$ for quartz measurements (Table 2), represents the relative standard deviation of the measured single aliquot $D_{e}$ distribution of samples obtained using the 'central age model' (Galbraith et al., 1999). To compare the dispersion of the $D_{e}$ values in the present study to that of a well bleached sample one aeolian sample from southern Cauvery Delta was analysed and it showed an overdispersion value of $3 \%$ for well bleached sample. This compares with some of the over-dispersion values reported by Arnold and Roberts (2009).

Several age models (e.g. Olley et al., 1998; Galbraith et al., 1999; Fuchs and Lang, 2001; Lepper and McKeever, 2002) have been put forward to extract true burial age from a distorted distribution. Modelling studies of multigrain $D_{e}$ distributions (Arnold and Roberts, 2009) suggested the use of CAM (central age model) where the samples are fully bleached and undisturbed; and MAM (minimum age model) to heterogeneously bleached samples with few fully bleached grains. The 'phantom' dose populations created in the second to fourth quartiles have no influence on identifying the $D_{e}$ values corresponding to well bleached grains when using MAM (Arnold and Roberts, 2009). From the $D_{e}$ distributions (Fig. 4), it was evident that the differential bleaching history of individual grains leads to the formation of small discrete popula- tions in the lower tail with remaining $D_{e}$ values falling in the middle to upper part of the distribution. The effect of varied light exposure to individual grains in a turbid water flow would result in sediment containing grains with a continuum of residual $D_{e}$ values at deposition, rather than discrete populations (Rodnight et al., 2006). In some instances a continuum of $D_{e}$ values were observed towards the upper part of the distribution. MAM effectively identified this lower population which most probably corresponds to the latest event of light exposure. However, only single-grain dating is capable of providing the true minimum-age estimate for most non-aeolian sediments (e.g., Duller, 2008; Berger et al., 2009).

\section{RESULTS}

All samples from the Utharangudi core were analysed for quartz and K-feldspar. For Valangaiman core only Kfeldspar dating was carried out because all but one of the quartz samples from the other core were near luminescence saturation. The summaries of results from the OSL dating of quartz and the IRSL dating of feldspar grains from both cores are given in the Tables 2 and 3. The calculated values for internal dose rate and total dose rate of K-feldspar grains in the study are summarised in the Table 1. The internal $\mathrm{K}$ content $(\sim 12 \%)$ in the samples from the present study is consistent with previous studies (Huntley and Baril, 1997; Zhao and Li, 2005), where as the concentrations of $U(0.045 \mathrm{ppm})$, Th $(0.25 \mathrm{ppm})$ and $\mathrm{Rb}(0.33 \mathrm{ppm})$ were very low.

The quartz age estimates are denoted as OSL, and the feldspar estimates are denoted as post-IR IRSL in the following discussions. Final $D_{e}$ values were obtained using both the MAM and weighted mean of $D_{e}$ value. The post-IR IRSL ages for feldspar samples discussed in the text represents fading corrected MAM ages unless otherwise specified. 

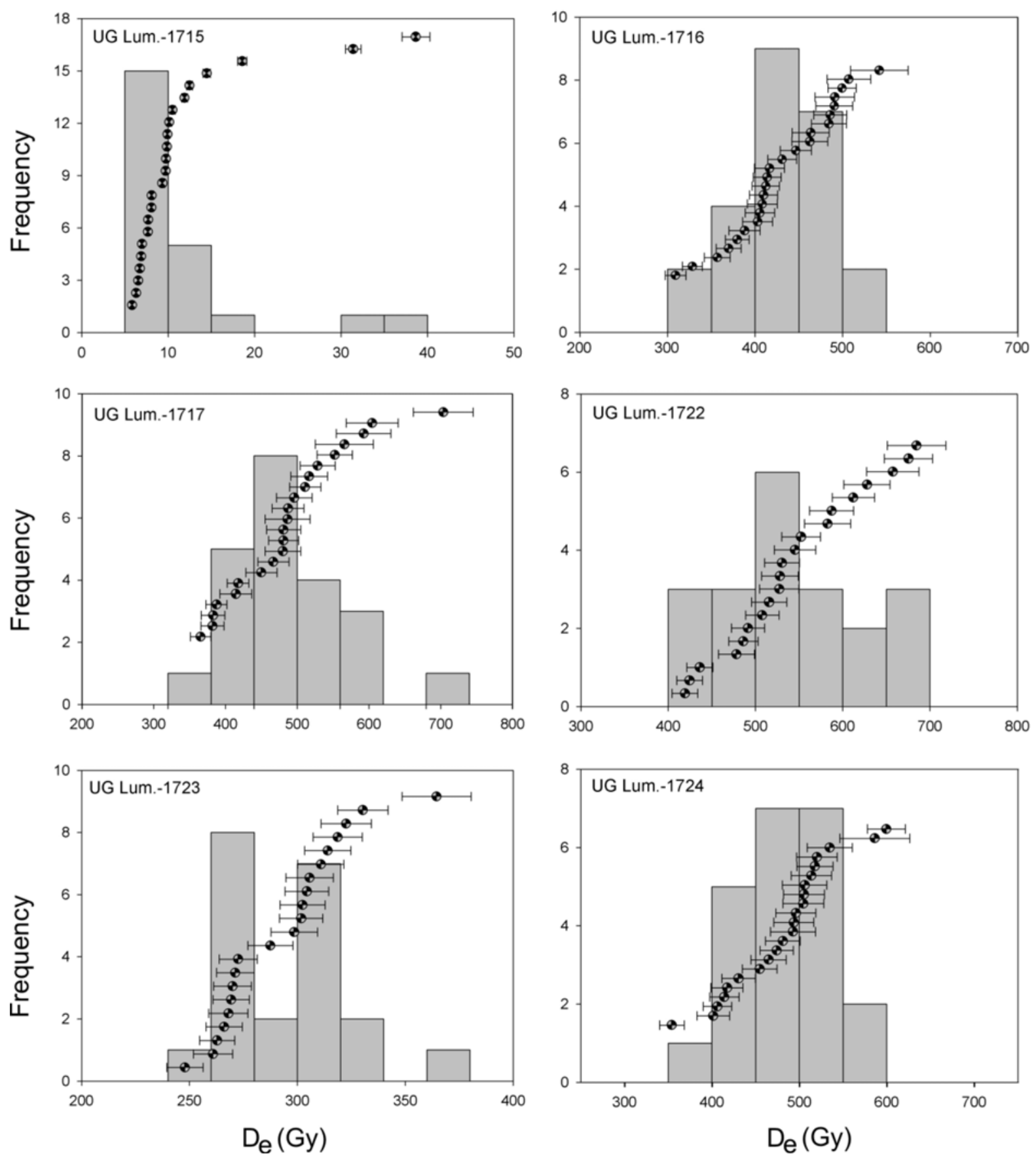

Fig. 4. The $D_{e}$ distributions of selected samples are shown as frequency histograms with individual $D_{e}$ values are plotted in ranked order.

Quartz sample UG Lum.-1715 of the Uttarangudi core taken from a depth of $3.05 \mathrm{~m}$ gave MAM age of $4 \pm 1 \mathrm{ka}$. As mentioned in section 'OSL of Quartz', quartz doseresponse curves from the remaining samples were near saturation. The protocol uses an identical heat treatment of $250^{\circ} \mathrm{C}$ for $60 \mathrm{~s}$ prior to the regenerated and test dose IRSL measurements and a $40 \mathrm{~s}$ high temperature $\left(290^{\circ} \mathrm{C}\right)$ hot bleach at the end of each cycle. The IRSL signal was first measured at $50^{\circ} \mathrm{C}$ and then at $225^{\circ} \mathrm{C}$ for $100 \mathrm{~s}$. The $D_{e}$ values were calculated for both stimulation temperatures by integrating the initial $2 \mathrm{~s}$ of IRSL signal with the last $10 \mathrm{~s}$ of signal subtracted as background. However, the quartz age estimates can still provide a possible lower limit of the depositional age. The ages for all the samples which were near saturation were calculated using the weighted mean (not MAM) of the measured $D_{e}$ value from different aliquots, as it shows only the possible minimum age of deposition. Quartz from the remaining samples (UGLum.-1716-1722) in the Uttarangudi core gave minimum OSL age estimates of $>82-197 \mathrm{ka}$.

The K-feldspar samples from the Utharangudi core displayed good signal properties inferred from the doseresponse curve of the individual aliquots. In most cases the samples are exceptionally bright, giving natural photon counts of $\sim 10^{6}$ counts/s. Therefore neutral density filters (ND.1/ ND.2) were employed to reduce the high 
signal intensity reaching the PMT. For the Utharangudi core the uppermost sample, UG Lum.-1715 which yields a post-IR IRSL age of $4 \pm 1 \mathrm{ka}$, is in good agreement with the quartz OSL age of the same sample. The post-IR IRSL age of sample UG Lum.-1716 is $193 \pm 28 \mathrm{ka}$ and that of UG Lum.-1717 is $212 \pm 31 \mathrm{ka}$. For samples UG Lum.1718 and UG Lum.-1719, the post-IR IRSL ages are $273 \pm 37 \mathrm{ka}$ and $375 \pm 47 \mathrm{ka}$ respectively. UG Lum.-1720 collected from a depth of $37.3 \mathrm{~m}$ gives a depositional age of $354 \pm 50 \mathrm{ka}$. Two samples UG Lum.-1721 and UG Lum.-1722 collected below this layer provide post-IR IRSL ages of $308 \pm 41 \mathrm{ka}$ and $364 \pm 52$ ka respectively.

The Valangaiman core, sample VM Lum.-1725 collected from the upper part of the core at a depth of $0.91 \mathrm{~m}$ give a post-IR IRSL ages of $0.8 \pm 0.1 \mathrm{ka}$. Two samples VM Lum. - 1723 and VM Lum.-1724 collected at depths of $4.7 \mathrm{~m}$ and $36.2 \mathrm{~m}$ revealed depositional ages of $108 \pm 14 \mathrm{ka}$ and $209 \pm 29 \mathrm{ka}$ respectively.

For comparison between the results of post-IR at $225^{\circ} \mathrm{C}$ and IRSL at $50^{\circ} \mathrm{C}$ method, we used the fading corrected ages calculated from the weighted mean of the distribution because for a few samples MAM could not be used to calculate the $D_{e}$ values. In general ages from post-IR and IRSL are in good agreement within the uncertainty except for sample UG Lum.-1718 where IRSL ages are much higher $(422 \pm 59 \mathrm{ka})$ than post-IR (fading corrected mean age of $293 \pm 39 \mathrm{ka})$. One possible reason for this could be the large g-value $(6.5 \pm 0.3 \%$ /decade $)$ of the IRSL signal applied for fading correction.

The laboratory fading rate for the post-IR signal measured at $225^{\circ} \mathrm{C}$ was much lower than the IRSL at $50^{\circ} \mathrm{C}$ signal which has been reported previously (Thomsen et al., 2008; Buylaert et al., 2009). For IRSL at $50^{\circ} \mathrm{C}$, the ' $\mathrm{g}$ '-value varied between $4.1 \pm 0.3$ to $14.7 \pm 0.6 \%$ /decade for the Uttarangudi core and $3.4 \pm 0.2$ to $12.5 \pm 0.7 \%$ /decade for the Valangaiman core. The fading rates of the post-IR IRSL signal for all the samples was within the range of $0.5-2.9 \% /$ decade except for sample UG Lum.-1722 which showed a relatively high fading with a ' $g$ ' value of $5.4 \pm 0.1 \%$ /decade. For both cores the younger samples showed higher fading compared to the older samples. In two samples (UG Lum.-1715 and UG Lum.-1722) correction for fading of IRSL signals could not be applied due to the large ' $\mathrm{g}$ ' values

\section{DISCUSSION}

We observed that the OSL signal in quartz has a low near-saturation dose with an average $D_{0}$ of $52 \pm 5 \mathrm{~Gy}(\mathrm{n}=$ 8). Jaiswal et al. (2009) found that quartz reaches saturation at $\sim 130$ Gy for pit samples collected from inland areas of river Cauvery. In spite of this, we were able to compare quartz and K-feldspar age estimates for the youngest sample. This comparison validated our procedures. In the Valangaiman core one can identify repeated flooding events with the occurrence of medium to coarse sand with pebbles at the bottom showing fluvial aggradations. The presence of clay beds indicates the recession of flood water or deposition of suspended load in areas further away from the main channel. The core also exhibits a few layers of mud cracks within the clay strata which suggest the occurrence of intense and repeated drying events during the deposition of the middle part of the core. Presence of high silt content in this layer suggests their deposition in an area far from the main channel where the river had low energy and laid down much of its suspended load. The post-IR IRSL age for VM Lum.1725 is the youngest of all the derived ages $(0.8 \pm 0.1 \mathrm{ka})$. This is stratigraphically reasonable as this sample is $\sim 1 \mathrm{~m}$ below the surface. Another sample from the same core (VMLum.-1723) at a depth of $4.7 \mathrm{~m}$ shows an age corresponding to MIS-5 (108 $\pm 14 \mathrm{ka})$ which demonstrates a large hiatus in sedimentation between these two relatively close layers. This hiatus is probably due to either a lateral shift in the river channel or the erosion of intermittent layers. The sample collected from a layer of medium sand with pebble at the lower part of the core (VMLum.-1724) gives an upper Middle Pleistocene age (209 $\pm 29 \mathrm{ka}$; MIS7) suggesting a time of active fluvial aggradations in the region during this period.

In the Utharangudi core (apart from the upper few meters of clay) the majority of the core is composed of fine, medium to coarse sand except for few events marking the deposition of coarser sediments up to size of pebbles, particularly at depth of $\sim 40 \mathrm{~m}$. Both the OSL and post-IR IRSL dating of sample UG Lum.-1715 provide identical late Holocene ages (4 ka) at a depth of $3 \mathrm{~m}$. The second and third youngest samples collected at depths of 9m (UGLum.-1716) and 13.6 m (UG Lum.-1717) show upper Middle Pleistocene ages $(193 \pm 28 \mathrm{ka}$ and $212 \pm 31 \mathrm{ka}$; MIS-6, MIS-7) and indicate a gap in sedimentation similar to the one observed in Valangaiman core. UGLum.-1718 at a depth of $28.5 \mathrm{~m}$ above the pebble layer reveals a post-IR IRSL age of $273 \pm 37 \mathrm{ka}$, possibly suggesting that sand was deposited during MIS-8. Below this sample, however, both IR and post-IR IRSL ages do not show any significant increase in age with depth, ranging between $\sim 300-375 \mathrm{ka}$. This suggests that either all these sediments were deposited at around $\sim 300$ $375 \mathrm{ka}$ (MIS-9, MIS-10), or the ages of the samples are beyond the limit of the correction method for anomalous fading. Similar apparent age saturation at $\sim 350 \mathrm{ka}$ (fading-corrected IRSL ages using the observed fading rate of $2.6 \%$ ) was reported by Wallinga et al. (2007) from core samples from the Roer Valley Graben.

The Utharangudi site appears to have remained a distal deltaic environment as observed by the general fine nature of the sediments except for thick unsorted lateritic pebbly layer at $\sim 40 \mathrm{~m}$ depth and similar minor layers inbetween. This lateritic layer may have formed during a prolonged period of fluvial non deposition or may have been derived from rapid high energy source such as massive flood events. To the west of Utharangudi site the delta is bordered by Pleistocene laterite covered MioPliocene sediments forming an elevated region. The presence of N-S lineaments (Tanjore-Avadaiyarkoil lineament and Kumbakonam-Muttupet lineament) in this region with dissected and undissected Miocene-Pliocene sandstone block on either side has been reported by Ramasamy (2006b). The non fluvial nature of the lateritic horizon at $40 \mathrm{~m}$ depth bounded above and below by typical fluvial sediments suggests that it was derived from uncovering of Mio-Pliocene sediments to the west. Possibly, it records some tectonic disturbance in this region 
during this period which could have triggered mass flow of lateritic cover over the Mio-Pliocene sediments. It is known that rivers in the arid and semi-arid environments are capable of carrying large volume of sediments during episodic storms when the area is devoid of vegetation (Juyal et al., 2006). Another possible implication of the layer of lateritic soil $(\sim 40 \mathrm{~m})$ is that it was deposited during seasonal storms or continuous water discharge during heavy rain. A heavy surge of storm water may have caused the river to change its course from the prevailing river channel through the dissected unit and this would have caused deposition of upper weathered lateritic soil in the immediate low lying areas and further incision channel widening would have brought plenty of sediments into the area. The occurrence of red lateritic soil has been reported in earlier studies from other sections in this area (Sarma, 1978) and another core (not included in the present study) recovered from the vicinity of the Uttarangudi core displayed identical features with red laterite soil layer at similar depths (P. Singh, personal communication, 2009) and this corroborates the proposed mass flow event which occurred during MIS-9 to MIS10 .

\section{CONCLUSIONS}

The internal dose rate of K-feldspar grains shows that $\mathrm{K}$ content in the sample contributes to about $\sim 98 \%$ of internal dose rate of the sample. The results of our chronological study of two cores from the Cauvery deltaic region reveal that except for a small upper layer of Holocene sediments ( $\sim 5 \mathrm{~m}$ depth), the majority of the upper $\sim 50 \mathrm{~m}$ of subsurface sediments of Cauvery Delta were deposited during the period of upper Middle Pleistocene to Upper Pleistocene (MIS-5 to MIS-10). The near surface sample in the core Valangaiman showed modern age. Both cores analysed in the study demonstrated a relatively large hiatus in the sedimentation with in the period of middle Holocene to Upper Pleistocene (MIS-5). This was probably due to the lateral migration of streams which hindered the sediment supply in to the region or continuous removal of upper sediments due to erosion.

\section{ACKNOWLEDGEMENTS}

This research has been supported by Leibniz DAAD fellowship funded by the German Academic Exchange Service (DAAD) and the Leibniz Institute for Applied Geophysics (LIAG), Hannover, which is greatly acknowledged. P.S. and R.R thank Department of Science and Technology (DST), Government of India for providing the funds for the collection of cores under the Shallow Subsurface Studies (SSS) programme. The authors are thankful to the anonymous reviewers who provided thoughtful suggestions and detailed review on this manuscript. Dr. Jens Stummeyer and Mr. Bodo Harazim from the Federal Institute for Geosciences and Natural Resources (BGR), Hannover are thanked for the ICPMS/OES analysis. P.S. is thankful to Mr. Malik Zubair Ahmad for his help during field work and compiling litho-logs. L.A. is grateful to Dr. Srinivasalu, Assistant professor, Department of Geology, Anna University,
India and Christine Thiel, LIAG for providing useful suggestions.

\section{REFERENCES}

Adamiec G and Aitken MJ, 1998. Dose-rate conversion factors: update. Ancient TL 16: 37-49.

Aitken MJ, 1998. Introduction to Optical Dating. Oxford, Oxford University Press: $262 \mathrm{pp}$.

Aitken MJ, 1985. Thermoluminescence Dating. London, Academic Press: $359 \mathrm{pp}$.

Arnold LJ and Roberts RG, 2009. Stochastic modelling of multi-grain equivalent dose $\left(D_{e}\right)$ distributions: Implications for OSL dating of sediment mixtures. Quaternary Geochronology 4: 204-230, DOI 10.1016/j.quageo.2008.12.001.

Babu PVLP, 1991. Cauvery delta- its past and present. Memoir of Geological Society of India 22: 91-101.

Berger GW, Post S, and Wenker C, 2009. Single and multigrain quartz luminescence dating of irrigation-channel features in Santa $\mathrm{Fe}$, New Mexico. Geoarchaeology 24: 383-401, DOI 10.1002/gea.20271.

Bridgland DR and Westaway R, 2008. Preservation patterns of Late Cenozoic fluvial deposits and their implications: results from IGCP 449. Quaternary International 189(1): 5-38, DOI 10.1016/j.quaint.2007.08.036.

Buylaert JP, Murray AS, Thomsen KJ and Jain M, 2009. Testing the potential of an elevated temperature IRSL signal from K-feldspar. Radiation Measurements 44: 560-565, DOI 10.1016/j.radmeas.2009.02.007.

Chandra K, Philip PC, Sridharan P, Chopra VS, Brahmaji Rao and Saha PK, 1991. Petroleum source-rock potentials of the cretaceous transgressive-regressive sedimentary sequences of the Cauvery Basin. Journal of Southeast Asian Earth Sciences 5(1-4): 367-371, DOI 10.1016/0743-9547(91)90050-8.

Chandra S, Rhodes E and Richards KS, 2007. Luminescence dating of late Quaternary fluvial sediments in the Rapti Basin, north-central Gangetic plains. Quaternary International 159: 47-56, DOI 10.1016/j.quaint.2006.08.011.

Das S, 1991. Hydrogeological features of deltas and estuarine tracts of India. Memoir of Geological Society of India 22: 183-225.

Duller GAT, 2003. Distinguishing quartz and feldspar in single grain luminescence measurements. Radiation Measurements 37: 161165, DOI 10.1016/S1350-4487(02)00170-1.

Duller GAT, 2008. Single grain optical dating of Quaternary sediments: why aliquots size matters in luminescence dating. Boreas 37: 589612, DOI 10.1111/j.1502-3885.2008.00051.x.

Fuchs M and Lang A, 2001. OSL dating of coarse-grain fluvial quartz using Single-Aliquot protocols on sediments from NEPeloponnese, Greece. Quaternary Science Reviews 20: 783-787, DOI 10.1016/S0277-3791(00)00040-8.

Galbraith RF, Roberts RG, Laslett GM, Yoshida H and Olley JM, 1999. Optical dating of single and multiple grains of quartz from Jinmium rock shelter, northern Australia. Part I experimental design and statistical models. Archaeometry 41: 339-364, DOI 10.1111/j.1475-4754.1999.tb00987.x.

Gibling MR, Sinha R, Roy NG, Tandon SK and Jain M, 2008. Quaternary fluvial and aeolian deposits on the Belan River, India: paleoclimatic setting of Paleolithic to Neolithic archeological sites over the past 85,000 years. Quaternary Science Reviews 27(3-4): 391410, DOI 10.1016/j.quascirev.2007.11.001.

Godfrey-Smith DI, Huntley DJ and Chen WH, 1988. Optical dating studies of quartz and feldspar sediment extracts. Quaternary Science Reviews 7: 373-380, DOI 10.1016/0277-3791(88)90032-7.

Huntley DJ and Baril MR, 1997. The K content of the K-feldspars being measured in optical dating or in thermoluminescence dating. Ancient TL 15: 11-13.

Huntley DJ and Lamothe M, 2001. Ubiquity of anomalous fading in Kfeldspars and the measurement and correction for it in optical dating. Canadian Journal of Earth Sciences 38: 1093-1106, DOI 10.1139/cjes-38-7-1093.

Jain M, Tandon SK, Singhvi AK, Mishra S and Bhatt SC, 2005. Quaternary alluvial stratigraphical development in a desert setting: A case study from the Luni River basin, Thar Desert of western India. In: Blum M and Marriott S, eds, Fluvial Sedimentology VII, International Association of Sedimentologists. Special Publication 35: 349-371, DOI 10.1002/9781444304350.ch19.

Jaiswal MK, Chen YG, Kale VS and Achyuthan H, 2009. Residual luminescence in quartz from slack water deposits in Kaveri basin, 
south india: A single aliquot approach. Geochronometria 33: 1-8, DOI 10.2478/v10003-009-0009-1.

Juyal N, Raj R, Maurya DM, Chamyal LS and Singhvi AK, 2000. Chronology of Late Pleistocene environmental changes in the lower Mahi basin, western India. Journal of Quaternary Science: 501-508, DOI 10.1002/1099-1417(200007)15:5<501::AIDJQS528>3.0.CO;2-J

Juyal N, Chamyal LS, Bhandari S, Bhushan R and Singhvi AK, 2006. Continental record of the southwest monsoon during the last 130 ka: evidence from the southern margin of the Thar Desert, India. Quaternary Science Reviews 25: 2632-2650, DOI 10.1016/j.quascirev.2005.07.020.

Kale VS, Singhvi AK, Mishra PK and Banerjee D, 2000. Sedimentary records and luminescence chronology of Late Holocene palaeofloods in the Luni River, Thar Desert, northwestern India. $\mathrm{Ca}$ tena 40: 337-358, DOI 10.1016/S0341-8162(00)00091-6.

Klasen N, Fiebig M, Preusser F and Radtke U, 2006. Luminescence properties of glaciofluvial sediments from the Bavarian Alpine Foreland. Radiation Measurements 41: 866-870, DOI 10.1016/j.radmeas.2006.04.014.

Kumar SP, 1983. Geology and hydrocarbon prospects of KrishnaGodavari and Cauvery Basin. Petroleum Asia Journal 6: 60-65.

Kunz A, Frechen M, Ramesh R and Urban B, 2010. Luminescence dating of Late Holocene dunes showing remnants of early settlement in Cuddalore and evidence of monsoon activity in south east India. Quaternary International 222: 194-208, DOI 10.1016/j.quaint.2009.10.042.

Lepper K and McKeever SWS, 2002. An objective methodology for dose dispersion analysis. Radiation Protection Dosimetry 101(14): 349-352.

Li B and Li S-H, 2006. Comparison of $D_{e}$ estimates using the fast component and the medium component of quartz OSL. Radiation Measurements 41: 125-136, DOI 10.1016/j.radmeas.2005.06.037.

Li B, Li SH, and Wintle AG, 2008. Overcoming environmental dose rate changes in luminescence dating of waterlain deposits. Geochronometria 30: 33-40, DOI 10.2478/v10003-008-0003-z.

Mejdahl V, 1979. Thermoluminescence dating: beta-dose attenuation in quartz grains. Archaeometry 21: 61-72, DOI 10.1111/j.14754754.1979.tb00241.x.

Murray AS and Wintle AG, 2000. Luminescence dating of quartz using an improved single-aliquot regenerative-dose protocol. Radiation Measurements 32: 57-73, DOI 10.1016/S1350-4487(99)00253-X.

Olley JM, Caitcheon GG and Murray AS, 1998. The distribution of apparent dose as determined by optically-stimulated luminescence in small aliquots of fluvial quartz: Implications for dating young samples. Quaternary Science Reviews (Quaternary Geochronology) 17: 1033-1040, DOI 10.1016/S0277-3791(97)00090-5.

Olley JM, Caitcheon GG and Roberts RG, 1999. The origin of dose distributions in fluvial sediments, and the prospect ofdating single grains from fluvial deposits using optically stimulated luminescence. Radiation Measurements 30: 207-217, DOI 10.1016/S13504487(99)00040-2.

Pawley SM, Toms P, Armitage SJ and Rose J, 2009. Quartz luminescence dating of Anglian Stage (MIS-12) fluvial sediments: Comparison of SAR age estimates to the terrace chronology of the Middle Thames valley, UK. Quaternary Geochronology, DOI 10.1016/j.quageo.2009.09.013: 1-14.

Ramasamy SM, 2006a. Holocene Tectonics Revealed by Tamil Nadu Deltas, India. Journal of Geological Society of India, 67(5): 637648.

Ramasamy SM, 2006b. Remote Sensing and Active tectonics of South India. International Journal of Remote Sensing 27(20): 4397-4431, DOI 10.1080/01431160500502603.

Ramasamy SM, Saravanavel J and Selvakumar R, 2006. Late Holocene geomorphic Evolution of Cauvery delta, Tamil Nadu, India. Journal of Geological Society of India, 67(5): 649-657

Ramesh R and Subramanian V, 1993. Geochemical characteristics of major tropical rivers of India. Hydrology of Warm Humid Regions (Proceedings of Yokohama Symposium) IAHS Publication no. 216: 157-164.

Ramanathan AL, Subramanian V and Das BK, 1996. Sediment and Heavy metal accumulation in the Cauvery Basin. Environmental Geology 27(3): 155-163, DOI 10.1007/BF00770427.

Readhead ML, 2002. Absorbed dose fraction for ${ }^{87} \mathrm{Rb} \beta$ - particles. Ancient TL 20: 25-27.

Rees-Jones J, 1995. Optical dating of young sediments using fine-grain quartz, Ancient TL 13: 9-14.
Rodnight H, Duller GAT, Wintle AG and Tooth S, 2006. Assessing the reproducibility and accuracy of optical dating of fluvial deposits.
Quaternary
Geochronology
$1: 109-120$
DOI

10.1016/j.quageo.2006.05.017.

Sarma A, 1978.The Paleoecology of Coastal Tamilnadu, South India: Chronology of Raised Beaches, In: Proceedings of the American Philosophical Society, 122 (6): 411- 426.

Sharma A and Rajamani V, 2000. Weathering of gneissic rocks in the upper reaches of Cauvery River, South India: implications to neotectonics of the region. Chemical Geology 166: 203-223, DOI 10.1016/S0009-2541(99)00222-3.

Sharma A and Rajamani V, 2001. Weathering of charnockites and sediment production in the catchment area of the Cauvery River, southern India. Sedimentary Geology 143: 169-184, DOI 10.1016/S0037-0738(01)00102-6.

Singarayer JS and Bailey RM, 2003. Further investigations of the quartz optically stimulated luminescence components using linear modulation. Radiation Measurements 37(4-5): 451-458, DOI $10.1016 / \mathrm{S} 1350-4487(03) 00062-3$.

Singh P and Rajamani V, 2001a. Geochemistry of the floodplain sediments of the Kaveri river, Southern India. Journal of Sedimentary Research 71(1): 50-60, DOI 10.1306/042800710050.

Singh P and Rajamani V, 2001b. REE Geochemistry of recent clastic sediments from the Kaveri floodplains, southern India: Implications to source area weathering and sedimentary processes. Geochimca et Cosmochimica Acta 65: 3093-3108, DOI 10.1016/S0016-7037(01)00636-6.

Sinha R, Bhattacharjee PS, Sangode SJ, Gibling MR, Tandon SK, Jain $\mathrm{M}$ and Godfrey-Smith D, 2007. Valley and interfluves sediments in the Southern Ganga plains, India: Exploring facies and magnetic signatures. Sedimentary Geology 210: 386-411, DOI 10.1016/j.sedgeo.2007.07.004.

Srivastava P, Sharma M and Singhvi AK, 2003a. Luminescence chronology of incision and channel pattern changes in the River Ganga, India. Geomorphology 51: 259-268, DOI 10.1016/S0169-555X(02)00223-4.

Srivastava P, Singh IB, Sharma M and Singhvi AK, 2003b. Luminescence chronometry and Late Quaternary geomorphic history of the Ganga Plain, India. Palaeogeography, Palaeoclimatology, Palaeoecology 197: 15-41, DOI 10.1016/S0031-0182(03)00384-5.

Thomas PJ, Jain M, Juyal N and Singhvi AK, 2005. Comparison of single-grain and small-aliquot OSL dose estimates in 3000 year old river sediments from South India. Radiation Measurements 39: 457-469, DOI 10.1016/j.radmeas.2004.07.005.

Thomas PJ, Juyal N, Kale VS and Singhvi AK 2007. Luminescence chronology of late Holocene extreme hydrological events in the upper Penner River basin, South India. Journal of Quaternary Science 22: 747-753, DOI 10.1002/jqs. 1097.

Thomsen KJ, Murray AS, Jain M and Bøtter-Jensen L, 2008. Laboratory fading rates of various luminescence signals from feldsparrich sediment extracts. Radiation Measurements 43: 1474-1486, DOI 10.1016/j.radmeas.2008.06.002.

Vaidyanathan R and Ramakrishnan M, 2008. Geology of India. Geological Society of India, Bangalore 2:557-994.

Valdiya KS, 2001. Tectonic resurgence of the Mysore plateau and surrounding regions in cratonic southern India. Current Science 81:1068-1089

Vandenberghe D, De Corte F, Buylaert JP, Kučera J and Van den haute $\mathrm{P}, 2008$. On the internal radioactivity in quartz, Radiation Measurements 43: 771-775, DOI 10.1016/j.radmeas.2008.01.016.

Wallinga J, Murray AS, Duller GAT and Törnqvist TE, 2001. Testing optically stimulated luminescence dating of sand-sized quartz and feldspar from fluvial deposits. Earth and Planetary Science Letters 193: 617-630

Wallinga J, Bos AJJ, Dorenbos P, Murray AS and Schokker J, 2007. A test case for anomalous fading correction in IRSL dating. Quaternary Geochronology 2: 216-221, DOI 10.1016/j.quageo.2006.05.014.

Wintle AG, 2008. Luminescence dating: where it has been and where it is going? Boreas 37(4): 471-482, DOI $10.1111 / \mathrm{j} .1502-$ 3885.2008.00059.x.

Wintle AG and Murray AS, 2006. A review of quartz optically stimulated luminescence characteristics and their relevance in single aliquot regeneration dating protocols. Radiation Measurements 41: 369-391, DOI 10.1016/j.radmeas.2005.11.001.

Zhao $\mathrm{H}$ and $\mathrm{Li} \mathrm{SH}, 2005$. Internal dose rate to K-feldspar grains from radioactive elements other than potassium. Radiation Measurements 40: 84-93, DOI 10.1016/j.radmeas.2004.11.004. 